\title{
Large Planting Stock Type and Mechanical Release Effects on the Establishment Success of Picea glauca Plantations in Quebec, Canada
}

\author{
Nelson Thiffault, ${ }^{1,2}$ Benoit Lafleur, ${ }^{3}$ Vincent Roy, ${ }^{1,4}$ and Josianne DeBlois ${ }^{1}$ \\ ${ }^{1}$ Direction de la Recherche Forestière, Ministère des Ressources Naturelles et de la Faune du Québec, 2700 Rue Einstein, \\ Québec, QC, Canada G1P 3 W8 \\ ${ }^{2}$ Centre d’Étude de la Forêt, Université Laval, Québec, QC, Canada G1V 0A6 \\ ${ }^{3}$ Département des Sciences Biologiques, Université du Québec à Montréal, Montréal, QC, Canada H2X 1 Y4 \\ ${ }^{4}$ Natural Resources Canada, Canadian Forest Service, Laurentian Forestry Centre, 1055 du P.E.P.S., P.O. Box 10380, \\ Station. Sainte-Foy, Québec, QC, Canada G1V4C7
}

Correspondence should be addressed to Nelson Thiffault, nelson.thiffault@mrnf.gouv.qc.ca

Received 21 July 2011; Accepted 28 September 2011

Academic Editor: Guofan Shao

Copyright (C) 2012 Nelson Thiffault et al. This is an open access article distributed under the Creative Commons Attribution License, which permits unrestricted use, distribution, and reproduction in any medium, provided the original work is properly cited.

We established four experimental plantations to evaluate the main and interaction effects of timing (year of application) of mechanical release and stock type (containerized or bareroot) on the establishment success of large Picea glauca seedlings eight years after outplanting on high-competition sites in Quebec (Canada). We also monitored percent cover and height of target vegetation groups as well as the amount of photosynthetically active radiation available to crop trees. Our results indicate that the use of large containerized or bareroot stock had limited effects on seedling growth, although bareroot seedlings presented higher mortality than containerized seedlings. Mechanical release enhanced seedling growth, compared to the control. Delaying treatment by two years impacted crop tree dimensions, although differences were minimal. Survival was not affected. We conclude that large containerized seedlings should be favoured over bareroot stock for reforestation on high-competition sites and that the release guidelines developed for standard size seedlings are applicable to the large dimension P. glauca stock tested in this study.

\section{Introduction}

Plantation forestry can be used to meet a wide variety of ecological, economical, and social objectives [1]. The fulfillment of these objectives is based on the successful establishment and adequate growth of the planted seedlings. However, seedling growth and survival can be impaired by competition from opportunistic, fast-growing herbaceous, and woody species that capture resources at the expense of crop trees $[2,3]$. Hence, vegetation management is usually required to manage the course and rate of forest vegetation succession and achieve precise management objectives $[4,5]$.

Competition for light, water, nutrients, and growing space can be addressed through a variety of silvicultural tools [6]. As such, chemical vegetation management is an effective tool for conifer release in plantations [7]; it has been shown to lead to significant increases in stand volume compared to control conditions in studies throughout the world [8]. Moreover, pesticide use is argued to have limited environmental impacts when applied appropriately $[9,10]$. However, the use of chemical herbicides raises significant public and environmental concerns [11] and is generally incompatible with major land certification initiatives (e.g., [12]). As a result, many countries in which chemical release was common in the past are now experiencing a trend to reduce herbicide use [13]. In Quebec (Canada), chemical herbicides were banned for use on Crown forest lands in 2001 [14].

This context has forced the development of alternative approaches to vegetation management. Mechanical control of unwanted species and cultural treatments such as seedling culture are less controversial than chemical methods [11]. 
These treatments have been selected as the basis for vegetation management in Quebec, and release guidelines based on light availability to crop seedlings have been developed [15]. Depending on site fertility, mechanical release is applied between the second and fourth years following planting [14]; delaying treatment can lead to significant growth loss [16]. However, previous studies have demonstrated that large spruce (Picea spp.) seedlings (container volume $>300 \mathrm{~cm}^{3}$ ) are more competitive than standard-size stock types (container volume $=110 \mathrm{~cm}^{3}$ ) and are less affected by the presence of vegetative competition $[17,18]$. It is therefore necessary to evaluate how these new stock types interact with the actual release scenario and validate whether their superior competitive potential offers a broader window of intervention for release without risk of significant growth loss or increased mortality. Moreover, large seedlings can be produced either in containers or as bareroot stock. Field comparisons of containerized and bareroot seedlings are numerous (e.g., [19-22]). However, most studies have examined stock types of different initial dimensions (see [23]); few have investigated the relative performance of bareroot and containerized seedlings that are similar in size at the time of planting [24-26]. To our knowledge, the potential for interaction between these new stock types and timing of mechanical release treatments has not yet been quantified.

Our objectives were to evaluate the main and interaction effects of timing (year of application) of mechanical release and stock type on height, diameter, and survival of large white spruce (P. glauca (Moench) Voss) seedlings eight years after outplanting on high-competition sites. We also monitored percent cover and height of target vegetation groups as well as the amount of photosynthetically active radiation available to crop trees, to assess release treatment effects on the planted seedlings' competitive environment. To do so, we established four, well-replicated experimental plantations and assumed that large stock containerized and bareroot seedlings could sustain delay in the application of a mechanical release treatment until five years after outplanting without significant losses in growth and survival after eight growing seasons, compared to release three years after outplanting (which would be the current operational guideline for such sites). We also hypothesised that the type of large stock (bareroot or container) would have no significant impact on seedling performance after eight growing seasons.

\section{Materials and Methods}

2.1. Study Area and Sites Description. The study area is located in south central Quebec $\left(46^{\circ} 43^{\prime} 06^{\prime \prime} \mathrm{N} ; 73^{\circ} 16^{\prime} 10^{\prime \prime} \mathrm{W}\right)$ and is part of the sugar maple (Acer saccharum Marsh.) yellow birch (Betula alleghaniensis Britt.) bioclimatic domain described by Saucier et al. [27]. From 1971 to 2000, average annual temperature was $3.2^{\circ} \mathrm{C}$, average annual precipitation was $1079 \mathrm{~mm}$, with $25 \%$ falling during the growing season, and average number of degree-days $\left(>5^{\circ} \mathrm{C}\right)$ was 1600 (StAlexis-des-Monts weather station; [28]).

In October 1998, we selected four sites (1-3 ha each) within the study area, in stands that had been clearcut in August of the same year. The experimental sites (hereafter referred to as Jones 1, Jones 2, Parker 1, and Parker 2) were located $\sim 1-15 \mathrm{~km}$ from each other. Forest inventories conducted prior to harvest indicated that these mixed stands were dominated by P. glauca and Abies balsamea (L.) Mill. (\% basal area $>60 \%)$. Companion species at the Jones 1 and Jones 2 sites were intolerant hardwoods, predominately trembling aspen (Populus tremuloides Michx) and white birch (Betula papyrifera Marsh.). The hardwood component of Parker 1 and Parker 2 was dominated by yellow birch (Betula alleghaniensis Britt.) and other tolerant species. Residual merchantable stems were cut later during that fall and windrowed with a root-rake in October 1998 to prepare the sites for planting. On all sites, soils were characterized by a sandy loam texture.

\subsection{Experimental Design, Release Treatments, and Stock Types.} The seedlings were planted in June 1999. On each of the four sites, we established an experimental design consisting of a completely randomized split-plot design with 16 main plots, each measuring $12 \mathrm{~m} \times 20 \mathrm{~m}$. Each main plot was randomly selected to receive one of four vegetation management treatments. The first treatment (NC; four plots) consisted of eradicating competing vegetation using both a chemical herbicide (glyphosate, 1.5\% v:v in water; applied in August 1999 and August 2000) and repeated mechanical release treatments (performed in July-August 2001, 2002, 2003, 2004, and 2006). The objective of this treatment (NC) was to create and maintain plots with minimal (and if possible, no) competition for light. The second and third treatments consisted of applying mechanical release treatments with motor-manual brushsaws during either the third (REL3; eight plots) or the fifth (REL5; two plots) growing season after outplanting. Under both treatments, the mechanical release was conducted during the active growing season, which is the optimal period to obtain maximum effects on competing vegetation [29]. The fourth treatment (CT; two plots) consisted of control plots, that is, plots that were not submitted to any vegetation management treatment.

Each main plot was divided into two subplots, to which we randomly assigned planting of one of two large seedling stock types (container or bareroot). Both stock types were produced over two growing seasons (2-0) in a forest nursery from local seed sources. Containerized seedlings were produced in $340 \mathrm{~cm}^{3}$ containers. At the time of planting, the containerized and bareroot seedlings had mean heights and diameters at ground level ( \pm standard deviation) of 42.4 $( \pm 8.8) \mathrm{cm}$ and $7.6( \pm 1.3) \mathrm{mm}$, and $38.0( \pm 5.8) \mathrm{cm}$ and 9.6 $( \pm 1.7) \mathrm{mm}$, respectively. In each subplot, seedlings were planted in 6 rows of five seedlings each, according to a $2 \mathrm{~m} \times$ $2.5 \mathrm{~m}$ grid $\left(2000\right.$ stems ha $^{-1}$ ), for a total of $\sim 30$ seedlings per subplot. Planting was performed under operational conditions; planters were remunerated under a production-based system, following usual planting guidelines in terms of microsite selection and planting quality (e.g., depth, verticality, soil compaction).

2.3. Competing Vegetation. Within each main plot, three circular vegetation sampling plots $\left(5 \mathrm{~m}^{2}\right)$ were installed every 
$5 \mathrm{~m}$ along three equally spaced transects ( $5 \mathrm{~m}$ apart), the entire layout forming a 3 plots $\times 3$ plots grid centered in the main plot. Each of the four study sites included 144 vegetation sampling plots ( 16 main plots $\times 9$ sampling plots). Vegetation sampling was performed in July 2006 to characterize competing vegetation during the eighth growing season after planting (regardless of the stock type). For all woody and herbaceous species, percent cover was visually estimated in $5 \%$ classes, and the modal height of the dominant cover was estimated to the nearest $\mathrm{cm}$. Subsequently, competing species were grouped into five groups, that is, hardwood, ferns, herbaceous, noncommercial woody species, and conifers (Table 1). For any given group, cover values were summed over species, and height values were averaged.

2.4. Seedling Measurements. In each sub-plot, the six seedlings closest to the centre were identified using metal tags. The heights and ground-level diameters of these seedlings were measured immediately following planting. In October of each year between 1999 and 2006, the tagged seedlings were remeasured and classified as either living or dead. On each study site, 192 seedlings ( 16 main plots $\times 2$ stock types $\times 6$ seedlings) were monitored, for a total of 768 seedlings across the four sites.

2.5. Photosynthetically Active Radiation. In each sub-plot, we measured the amount of photosynthetically active radiation (PAR) reaching the upper half of two individual seedlings located in opposite corners of the plot. Following the method described by Jobidon [30], PAR measurements were made on sunny days using Sunfleck ceptometers, which each contained 80 photodiodes (Decagon Devices, Pullman, WA). Average upper-half readings for a given seedling were expressed as a percentage of the above-canopy light level (\%PAR). PAR measurements were performed once between mid-July and the end of August in 2001, 2002, 2003, and 2006 $(3,4,5$, and 8 years after planting, resp.).

2.6. Statistical Analyses. Percent cover of competing vegetation evaluated during the eighth growing season after planting was analyzed using a general linear model (GLM) with a beta distribution and a logit link function, whereas height was analyzed using a classic two-way analysis of variance (ANOVA) (with the groups analyzed separately). For these variables, vegetation management treatments and experimental sites were introduced in the model as fixed effect factors, as we suspected the distinct preharvest stand composition would significantly influence vegetation response to the release treatments. Given that these analyses revealed that the vegetation management treatment $\times$ experimental site interaction was not significant for most of the competing vegetation responses (see results), the sites were considered as a random effect for all further analyses, in order to maximize the potential for inferring seedling responses to treatments [31].

Seedling survival was analyzed using a stratified Cox proportional hazards model, with stock type as the stratification factor (because its effect on the mortality risk was not multiplicative; see results). Ground-level diameter, height, and the height/diameter ratio were analyzed using a linear mixed model for repeated measurements, using initial values as covariates. Vegetation management treatments (main plot factor) and stock types (sub-plot factor) were considered as fixed effect factors, as well as time (years), and all the interactions between these factors. In addition to sites, plots were considered as a random effect factor. Logistic regression was used to compare how \%PAR varied among vegetation management treatments over the first eight years after treatment, using a general linear mixed model (GLMM) with a beta distribution and a logit link function. The model was similar to the one used for seedling size analyses, except that it did not contain the stock type factor; analyses were performed on plot means.

Normality of the residuals was confirmed with ShapiroWilk's statistic when required, and homoscedasticity was visually validated using standard graphical methods. GLM and GLMM were performed using the GLIMMIX procedure of SAS 9.2 [32], whereas ANOVAs and linear mixed models for repeated measurements were performed using the MIXED procedure (with the Toeplitz covariance structure, to take into account the correlation between measures on the same experimental units when needed [33]). When required, we used a simulation-based approach as a multiple comparison adjustment of the $P$ values to assess the differences between vegetation management treatments. For seedling size, a priori contrasts were constructed during the eighth growing season using the CONTRAST statement, and no adjustment was used. Differences were deemed significant when $P<0.05$.

\section{Results}

3.1. Competing Vegetation. The percent cover of competing vegetation, as evaluated during the eighth growing season after planting, differed significantly among the vegetation management treatments (Figure 1; Table 2). We detected no significant interaction between sites and treatments for hardwood, ferns, noncommercial woody species, and conifer percent cover data, indicating that treatment effects were similar across sites. Control plots had a significantly higher percent cover of hardwood species than the other treatments, whereas NC plots had a significantly lower percent cover of hardwood species than the control plots, REL3 and REL5 plots; the percent cover of REL3 and REL5 was similar (Figure 1; Table 2). Regardless of the vegetation management treatments, percent cover of hardwoods was similar across the Jones 1 and Jones 2 sites, and higher on the Parker 2 site, compared to other sites. The Parker 1 site was similar to the Jones 2 site with regard to the percent cover of hardwoods. Plots where competing vegetation was regularly eradicated (i.e., NC) had a significantly lower percent cover of ferns and noncommercial woody species than the three other treatments, which were not significantly different from each other (Figure 1; Table 2). Regardless of vegetation management treatment, percent cover of ferns followed the pattern: Parker $1<$ Parker $2<$ Jones 1 = Jones 2 . The interaction between treatments and sites was significant for percent cover of 
TABLE 1: Plant species included in each vegetation group. Plant names were reviewed according to VASCAN (http://data.canadensys.net/vascan/search/), the Database of Vascular Plants of Canada.

\begin{tabular}{|c|c|c|c|c|}
\hline Hardwood & Fern & Herbaceous & Noncommercial & Conifer $^{1}$ \\
\hline $\begin{array}{l}\text { Acer rubrum } \\
\text { Linnaeus }\end{array}$ & $\begin{array}{l}\text { Dryopteris carthusiana } \\
\text { (Villars) H. P. Fuchs }\end{array}$ & $\begin{array}{l}\text { Anaphalis margaritacea } \\
\text { (Linnaeus) Bentham \& Hooker } \mathrm{f} .\end{array}$ & $\begin{array}{l}\text { Acer pensylvanicum } \\
\text { Linnaeus }\end{array}$ & $\begin{array}{l}\text { Abies balsamea } \\
\text { (Linnaeus) Miller }\end{array}$ \\
\hline $\begin{array}{l}\text { Acer saccharum } \\
\text { Marshall }\end{array}$ & $\begin{array}{l}\text { Onoclea sensibilis } \\
\text { Linnaeus }\end{array}$ & $\begin{array}{l}\text { Apocynum androsaemifolium } \\
\text { Linnaeus }\end{array}$ & Acer spicatum Lamarck & $\begin{array}{l}\text { Picea glauca } \\
\text { (Moench) Voss }\end{array}$ \\
\hline $\begin{array}{l}\text { Betula alleghaniensis } \\
\text { Britton }\end{array}$ & $\begin{array}{l}\text { Osmunda claytoniana } \\
\text { Linnaeus }\end{array}$ & $\begin{array}{l}\text { Aralia hispida } \\
\text { Ventenat }\end{array}$ & $\begin{array}{l}\text { Alnus incana subsp. } \\
\text { rugosa } \\
\text { (Du Roi) R. T. Clausen }\end{array}$ & $\begin{array}{l}\text { Picea mariana } \\
\text { (Miller) Britton, } \\
\text { Sterns \& Poggenburgh }\end{array}$ \\
\hline $\begin{array}{l}\text { Betula papyrifera } \\
\text { Marshall }\end{array}$ & $\begin{array}{l}\text { Osmundastrum } \\
\text { cinnamomeum } \\
\text { (Linnaeus) C. Presl }\end{array}$ & $\begin{array}{l}\text { Aralia nudicaulis } \\
\text { Linnaeus }\end{array}$ & $\begin{array}{l}\text { Amelanchier } \\
\text { Medikus }\end{array}$ & $\begin{array}{l}\text { Picea rubens } \\
\text { Sargent }\end{array}$ \\
\hline $\begin{array}{l}\text { Betula populifolia } \\
\text { Marshall }\end{array}$ & $\begin{array}{l}\text { Phegopteris connectilis } \\
\text { (Michaux) Watt }\end{array}$ & $\begin{array}{l}\text { Chamerion angustifolium } \\
\text { (Linnaeus) Holub subsp. } \\
\text { angustifolium }\end{array}$ & $\begin{array}{l}\text { Cornus stolonifera } \\
\text { Michaux }\end{array}$ & $\begin{array}{l}\text { Pinus resinosa } \\
\text { Solander ex Aiton }\end{array}$ \\
\hline $\begin{array}{l}\text { Fagus grandifolia } \\
\text { Ehrhart }\end{array}$ & $\begin{array}{l}\text { Pteridium aquilinum } \\
\text { (Linnaeus) Kuhn }\end{array}$ & $\begin{array}{l}\text { Epilobium coloratum } \\
\text { Sprengel }\end{array}$ & $\begin{array}{l}\text { Corylus cornuta } \\
\text { Marshall subsp. } \\
\text { cornuta }\end{array}$ & $\begin{array}{l}\text { Pinus strobus } \\
\text { Linnaeus }\end{array}$ \\
\hline $\begin{array}{l}\text { Fraxinus nigra } \\
\text { Marshall }\end{array}$ & $\begin{array}{l}\text { Thelypteris } \\
\text { noveboracensis } \\
\text { (Linnaeus) Nieuwland }\end{array}$ & $\begin{array}{l}\text { Hieracium } \\
\text { Linnaeus }\end{array}$ & $\begin{array}{l}\text { Diervilla lonicera } \\
\text { P. Miller }\end{array}$ & $\begin{array}{l}\text { Thuja occidentalis } \\
\text { Linnaeus }\end{array}$ \\
\hline $\begin{array}{l}\text { Populus balsamifera } \\
\text { Linnaeus }\end{array}$ & & $\begin{array}{l}\text { Kalmia angustifolia } \\
\text { Linnaeus }\end{array}$ & $\begin{array}{l}\text { Ilex mucronata } \\
\text { (Linnaeus) M. Powell, } \\
\text { V. Savolainen \& S. } \\
\text { Andrews }\end{array}$ & \\
\hline $\begin{array}{l}\text { Populus grandidentata } \\
\text { Michaux }\end{array}$ & & $\begin{array}{l}\text { Myrica gale } \\
\text { Linnaeus }\end{array}$ & $\begin{array}{l}\text { Lonicera canadensis } \\
\text { Bartram ex Marshall }\end{array}$ & \\
\hline $\begin{array}{l}\text { Populus tremuloides } \\
\text { Michaux }\end{array}$ & & $\begin{array}{l}\text { Oclemena acuminata } \\
\text { (Michaux) Greene }\end{array}$ & $\begin{array}{l}\text { Prunus pensylvanica } \\
\text { Linnaeus f. }\end{array}$ & \\
\hline \multirow[t]{7}{*}{$\begin{array}{l}\text { Ulmus americana } \\
\text { Linnaeus }\end{array}$} & & $\begin{array}{l}\text { Rubus allegheniensis } \\
\text { Porter }\end{array}$ & $\begin{array}{l}\text { Rhododendron } \\
\text { canadense } \\
\text { (Linnaeus) Torrey }\end{array}$ & \\
\hline & & $\begin{array}{l}\text { Rubus idaeus } \\
\text { Linnaeus subsp. idaeus }\end{array}$ & $\begin{array}{l}\text { Rhus typhina } \\
\text { Linnaeus }\end{array}$ & \\
\hline & & $\begin{array}{l}\text { Rubus pubescens } \\
\text { Rafinesque }\end{array}$ & $\begin{array}{l}\text { Ribes glandulosum } \\
\text { Grauer }\end{array}$ & \\
\hline & & $\begin{array}{l}\text { Solidago } \\
\text { Linnaeus }\end{array}$ & $\begin{array}{l}\text { Sambucus racemosa } \\
\text { subsp. pubens } \\
\text { (Michaux) Trautvetter } \\
\text { \& C.A. Meyer var. } \\
\text { pubens }\end{array}$ & \\
\hline & & $\begin{array}{l}\text { Solidago macrophylla } \\
\text { Pursh }\end{array}$ & $\begin{array}{l}\text { Viburnum lantanoides } \\
\text { Michaux }\end{array}$ & \\
\hline & & $\begin{array}{l}\text { Symphyotrichum puniceum } \\
\text { (Linnaeus) Á. Löve \& D. Löve } \\
\text { var. puniceum }\end{array}$ & $\begin{array}{l}\text { Viburnum nudum var. } \\
\text { cassinoides (Linnaeus) } \\
\text { Torrey \& A. Gray }\end{array}$ & \\
\hline & & Vitis riparia Michaux & & \\
\hline
\end{tabular}

${ }^{1}$ This group includes the planted seedlings (P. glauca).

herbaceous species (Table 2). On the Jones 2 site, NC plots had a significantly higher percent cover of herbaceous species than the control and REL3 plots; NC and REL5 were statistically similar. On the Jones 1, Parker 1, and Parker 2 sites, herbaceous cover did not differ significantly among treatments (Figure 1; Table 2).
The average modal height of the competing vegetation differed significantly among the vegetation management treatments (Figure 2; Table 2). The eighth-season hardwood height was significantly greater in control plots than that in the NC, REL3, and REL5 plots. Hardwood species in NC plots were significantly smaller than these in the other 

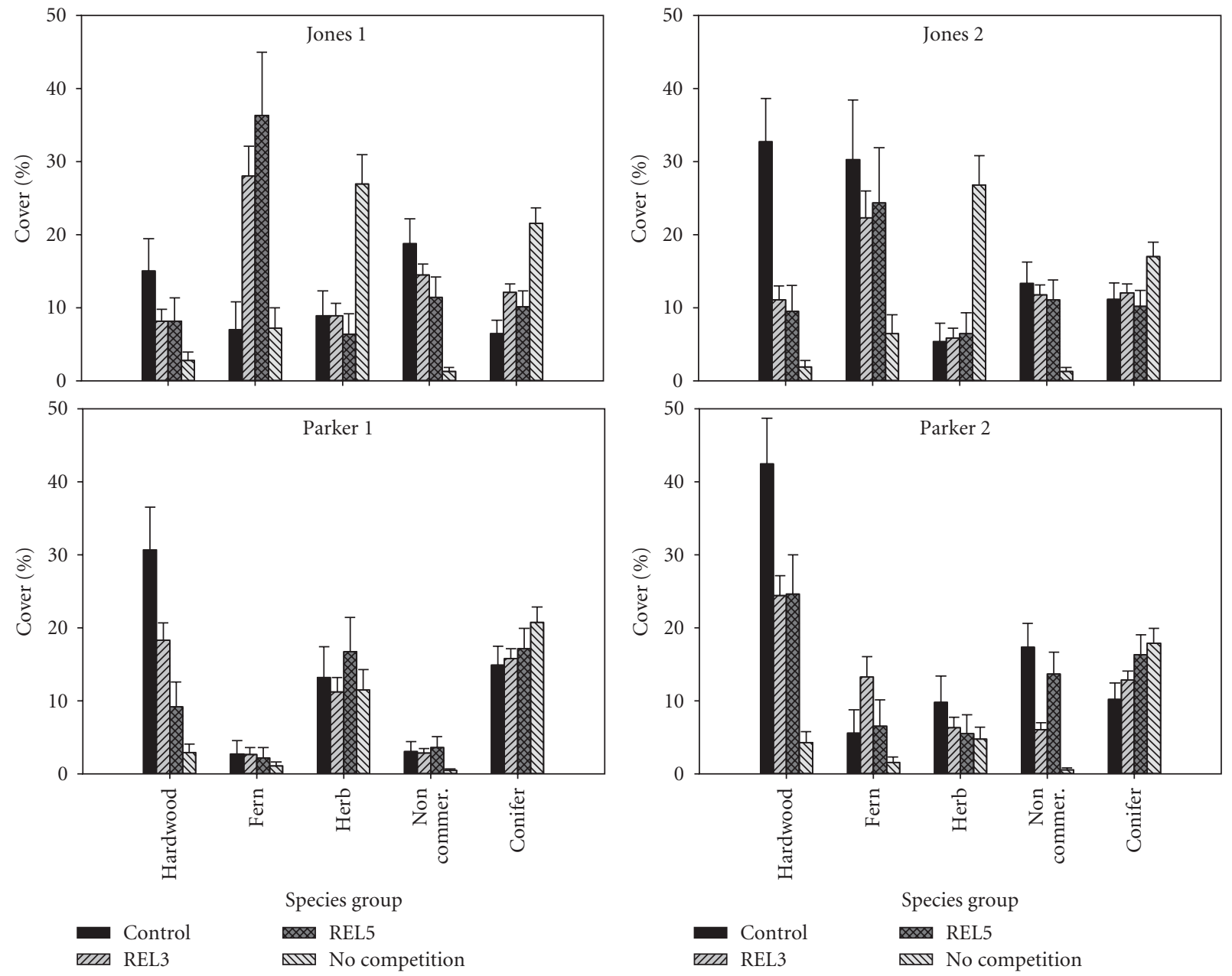

FIGURE 1: Average percent cover ( \pm standard error) of the principal groups of competing vegetation, as evaluated during the eighth growing season following planting of four experimental Picea glauca plantations established in south central Quebec (Canada). See Table 1 for a detailed description of each vegetation group. Treatments consisted of four intensities of vegetation management, including a control, mechanical release during the third growing season (REL3), mechanical release during the fifth growing season (REL5), and plots where competition for light was eliminated through repeated herbicide and mechanical release treatments (No competition: NC). Treatment effects were consistent across sites, except for the herbaceous species (refer to Table 2 for detailed ANOVA results). Data are presented separately for each site for clarity and convenience.

treatments, with a height statistically greater in REL3 plots compared to REL5 plots (Figure 2; Table 2). Regardless of vegetation management treatment, hardwood height was similar across the Parker 1 and Parker 2 sites, and Jones $1=$ Jones $2=$ Parker 2 . The fern cover was significantly shorter in the NC plots, compared to the REL3 plots, and exhibited the following pattern: Parker $1<$ Parker $2<$ Jones $1=$ Jones 2 (Figure 2; Table 2). The noncommercial species in the NC and REL5 plots were significantly shorter than those in the control plots, and there was no significant difference between the average modal height of noncommercial species in the REL3 and REL5 plots (Figure 2; Table 2). This result was consistent across all sites. Herbaceous species had similar heights across all treatments (Figure 2; Table 2).

3.2. Seedling Survival. Vegetation management treatments had no significant effect on seedling survival $(P=0.225)$, whereas there was a significant interaction between stock type and time $(P<0.001$; Figure 3$)$. After eight growing seasons, containerized seedlings had a higher survival probability than bareroot seedlings $(P=0.025)$. We detected no significant interaction between vegetation management treatment and stock type with regard to seedling survival $(P=0.266)$.

3.3. Seedling Size. Whereas there was a significant interactive effect between vegetation management treatments and time on seedling ground-level diameter $(P<0.001$; Figure 4$)$, stock type did not significantly affect this variable $(P=$ 0.371 ), and we detected no significant interaction between stock type and the other factors $(P \geq 0.109)$. After eight growing seasons, container and bareroot seedlings had ground-level diameters of $53.7 \mathrm{~mm}$ and $55.5 \mathrm{~mm}$, respectively (standard error $=0.9$ ). Seedlings growing in plots where 
TABLE 2: ANOVA results for competing vegetation variables.

\begin{tabular}{|c|c|c|c|c|}
\hline \multirow{2}{*}{ Species group ${ }^{1}$} & \multicolumn{2}{|c|}{ Percent cover } & \multicolumn{2}{|c|}{ Modal height } \\
\hline & $F$-value & Prob. $>F^{2}$ & $F$-value & Prob. $>F^{1}$ \\
\hline \multicolumn{5}{|l|}{ Hardwood } \\
\hline Vegetation management (VM) & 34.40 & $<0.001$ & 55.53 & $<0.001$ \\
\hline Site $(S)$ & 9.25 & $<0.001$ & 5.18 & 0.004 \\
\hline $\mathrm{VM} \times \mathrm{S}$ & 0.90 & 0.536 & 0.73 & 0.679 \\
\hline \multicolumn{5}{|l|}{ Fern } \\
\hline Vegetation management (VM) & 11.61 & $<0.001$ & 5.73 & 0.002 \\
\hline Site $(S)$ & 19.39 & $<0.001$ & 24.76 & $<0.001$ \\
\hline $\mathrm{VM} \times \mathrm{S}$ & 1.49 & 0.180 & 1.53 & 0.167 \\
\hline \multicolumn{5}{|l|}{ Herbaceous } \\
\hline Vegetation management (VM) & 5.88 & 0.002 & 0.33 & 0.801 \\
\hline Site $(S)$ & 3.76 & 0.017 & 4.63 & 0.006 \\
\hline $\mathrm{VM} \times \mathrm{S}$ & 3.80 & 0.001 & 0.80 & 0.622 \\
\hline \multicolumn{5}{|l|}{ Non commercial } \\
\hline Vegetation management (VM) & 33.92 & $<0.001$ & 7.89 & $<0.001$ \\
\hline Site $(S)$ & 13.39 & $<0.001$ & 3.04 & 0.038 \\
\hline $\mathrm{VM} \times \mathrm{S}$ & 1.76 & 0.100 & 1.40 & 0.216 \\
\hline \multicolumn{5}{|l|}{ Conifer } \\
\hline Vegetation management (VM) & 13.88 & $<0.001$ & 5.35 & 0.003 \\
\hline Site $(S)$ & 4.78 & 0.005 & 5.14 & 0.004 \\
\hline $\mathrm{VM} \times \mathrm{S}$ & 1.24 & 0.291 & 0.62 & 0.771 \\
\hline
\end{tabular}

${ }^{1}$ See Table 1 for a detailed description of each vegetation group.

${ }^{2}$ Values in bold are for interpretation.

most of the vegetation had been eradicated over the course of the entire experiment (i.e., NC treatment) had a significantly larger eighth-year ground-level diameters than seedlings from both mechanical release treatments (i.e., REL3 and REL5) $(P<0.001$; Figure 4). Likewise, seedlings growing in the plots that had been submitted to mechanical release (REL3 and REL5) had a significantly larger eighth-year ground-level diameters than those growing in control plots $(P<0.001$; Figure 4$)$. The eighth-year ground-level diameters of the seedlings in REL3 plots were statistically larger $(P=0.030)$ than those of the seedlings in REL5 plots.

Stock type and vegetation management treatments interacted with time to influence seedling height $(P<0.001$; Figure 5). Seedlings established in the REL3 treatment were significantly taller after eight growing seasons than those growing in the REL5 treatment $(P=0.001$; Figure 5(a)). Seedlings growing in the NC plots were significantly taller after eight years than those from the REL3 and REL5 treatments $(P<0.001)$, whereas we detected no significant differences between the control and the average height of seedlings in the REL3 and REL5 treatments $(P=0.983$; Figure $5(\mathrm{a})$ ). After eight growing seasons, there was no significant difference between stock types in terms of seedling height $(P=0.267$; Figure 5(b)).

Vegetation management and stock type influenced the height/diameter ratio, an effect that varied with time $(P<$ 0.001; Figure 6). After eight growing seasons, the REL3 and REL5 treatments resulted in seedlings having similar height/ diameter ratios $(P=0.130$; Figure $6(a))$, a value significantly higher than the one observed in NC plots $(P<0.001)$, but lower than that measured for seedlings from the control plots $(P<0.001)$. After eight growing seasons, we detected no significant difference between the height/diameter ratios of the two stock types $(P=0.735$; Figure $6(b))$.

3.4. Photosynthetically Active Radiation. The vegetation management treatments had a significant effect on \%PAR reaching the upper half of seedlings. From three to eight years after planting, the \%PAR reaching seedlings in control plots remained relatively constant (ca. 53\%), while during the same period, \%PAR increased in the REL3 and REL5 treatment plots (Figure 7). During the third growing season, $\%$ PAR did not differ significantly among treatments $(P=1)$. In years four and five, \%PAR was significantly higher in the REL3 treatment, compared to the REL5 and control treatments $(P \leq 0.005$; Figure 7$)$. During the eighth growing season, \%PAR in the REL5 treatment reached a level comparable to that measured in the REL3 treatment $(P=0.110)$, and both treatments presented a significantly higher \%PAR than the control treatment $(P<0.001$; Figure 7$)$.

\section{Discussion}

As expected, the growth of competing vegetation varied across sites, likely as a result of site-specific disturbance histories (which influence the availability of buried seed banks and propagules), preharvest stand composition and characteristics, and external seed sources, among other factors. 

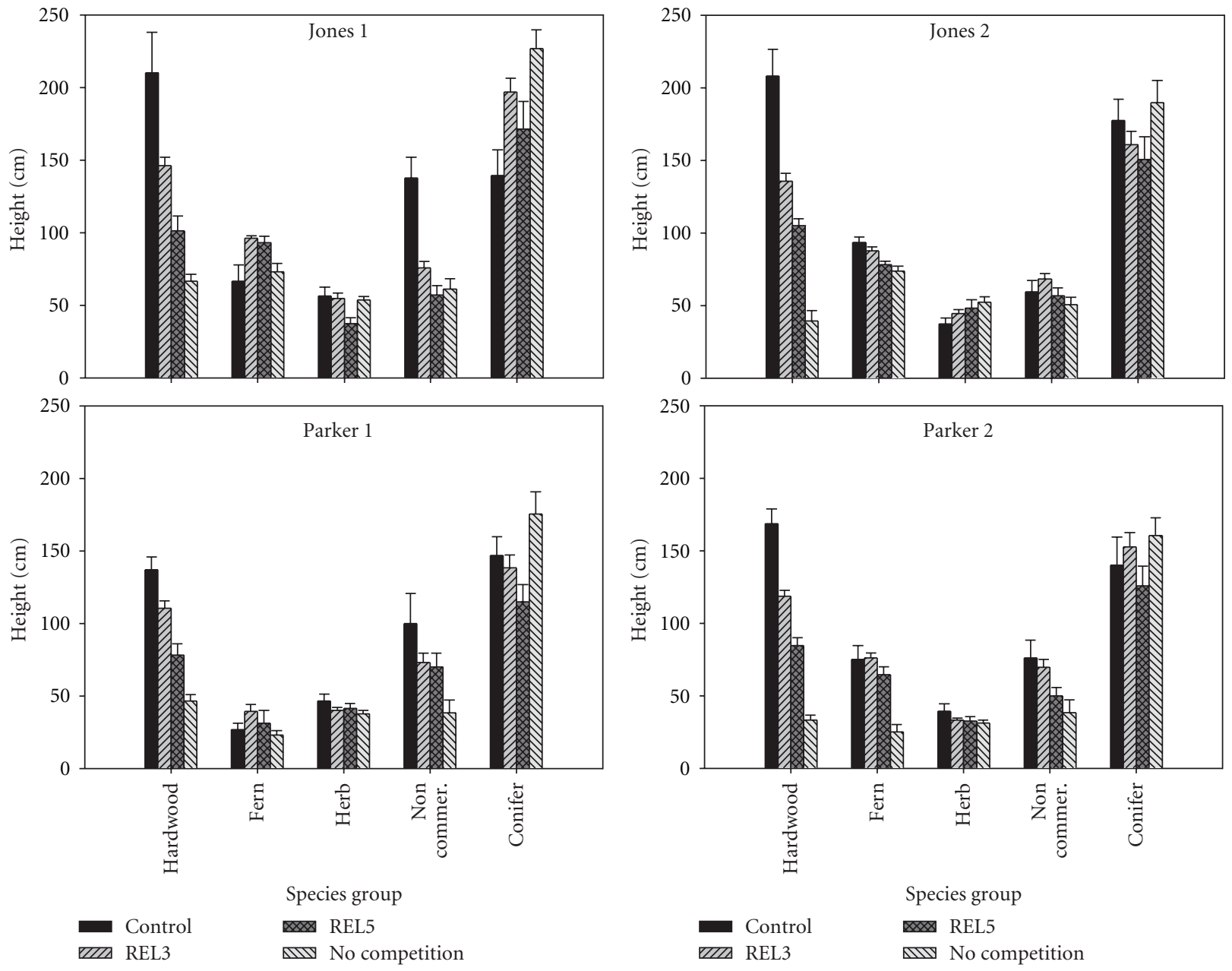

FIGURE 2: Average modal height ( \pm standard error) of the principal groups of competing vegetation, as evaluated during the eight growing season following planting of four experimental Picea glauca plantations established in south central Quebec (Canada). See Table 1 for a detailed description of each vegetation group. Treatments consisted of four intensities of vegetation management including a control, mechanical release during the third growing season (REL3), mechanical release during the fifth growing season (REL5), and plots where competition for light was eliminated through repeated herbicide and mechanical release treatments (No competition: NC). Treatment effects were consistent across sites (refer to Table 2 for detailed ANOVA results). Data are presented separately for each site for clarity and convenience.

These intersite differences in vegetation dynamics, as well as the general lack of interaction between vegetation management treatment and site (with the exception of herbaceous vegetation), strengthen the potential for using our results to infer the reaction of seedlings to manipulative treatments such as those applied in the present study.

Most studies that investigate the comparative performance of containerized and bareroot seedlings also include an important "initial size" effect [23]. Since many studies demonstrate that larger seedlings grow better than smaller seedlings in the presence of competing vegetation (e.g., [17, $34,35]$ ), it makes it difficult to make conclusions based on the sole effect of the seedling type (containerized versus bareroot) [36]. The stock types used in this study were of a similar size by silvicultural standards, which permitted us to investigate the influence of factors other than initial seedling dimension.
In this regard, our results indicate that the use of either large containerized or large bareroot stock for reforestation of white spruce has limited effects on early seedling growth. Both stock types resulted in saplings which had similar ground-level diameters over eight growing seasons after outplanting, and neither stock type presented an enhanced growth response to release (or conversely, suffered more from the competing pressure) compared to the other. We detected a significant interaction between stock type and year for height (the profiles were not parallel from year 0 to 3 ), but the curves converged after year 4 and remained parallel thereafter. As a result, in year 4 the height/diameter ratio of both stock types stabilized around a common value, in line with results obtained elsewhere for similar stock types [25]. Similar height/diameter ratios were obtained for containerized and bareroot seedlings, regardless of the vegetation management treatment to which they were subjected, further 


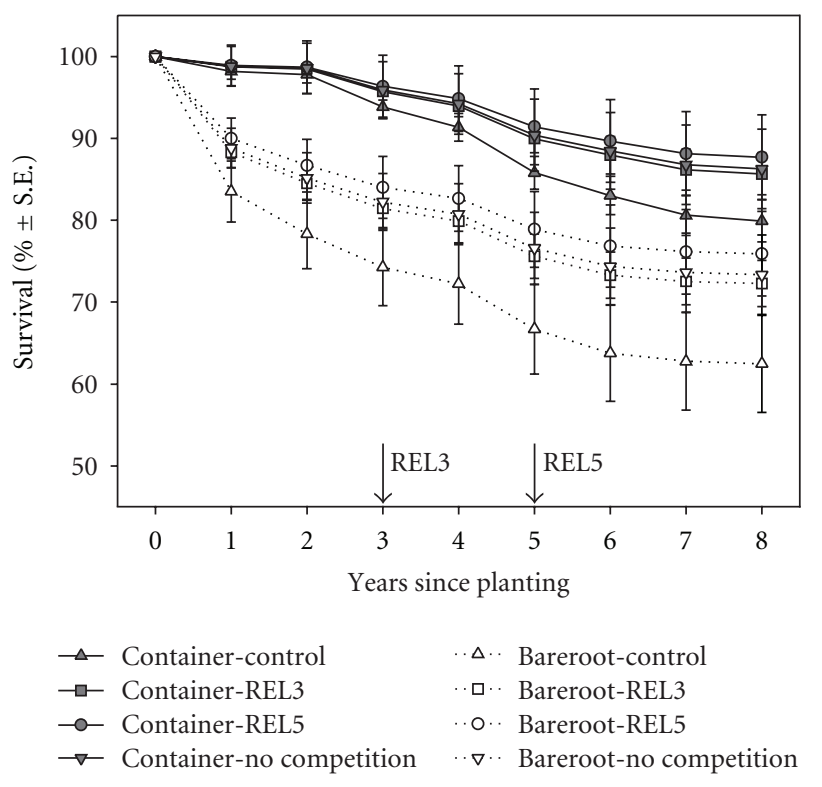

FIGURE 3: Seedling survival over eight growing seasons, for large containerized and bareroot Picea glauca seedlings outplanted in south central Quebec (Canada), and submitted to four intensities of vegetation management, including a control, mechanical release during the third growing season (REL3), mechanical release during the fifth growing season (REL5), and plots where competition for light was eliminated through repeated herbicide and mechanical release treatments (No competition: $\mathrm{NC}$ ).

supporting the assertion that both stock types compete equally well [37].

Although seedling growth was similar for both stock types, mortality was much higher in plots outplanted with bareroot seedlings compared to those planted with containerized seedlings. About half $(\sim 13 \%)$ of the bareroot mortality occurred during the first growing season. During the following years, survival of both stock types decreased at a similar rate. This increased mortality of the bareroot seedlings, compared to that of containerized stock, is not uncommon (e.g., [38]). The mortality rates we observed are similar to those reported by Trottier [39] for a subset of the operational plantations established in Quebec between 1986 and 1995 (741 M seedlings). Bareroot stocks are generally under greater water stress than containerized seedlings [40], and are more susceptible to be damaged during storage, handling, and planting operations [36].

Overall, these eight-year comparative results suggest that when available, large containerized seedlings should be favoured over bareroot stock for reforestation of sub-boreal sites. This recommendation is further supported when considering production costs, which are $\sim 20-30 \%$ higher in the province of Quebec for bareroot than for large dimension containerized seedlings [41].

Regardless of the stock type, the effects of vegetative competition on height, diameter, and survival were typical of those observed in other competition studies involving boreal conifers $[16,42]$. The differential effect of resource competition on height and diameter $[43,44]$ resulted in increased

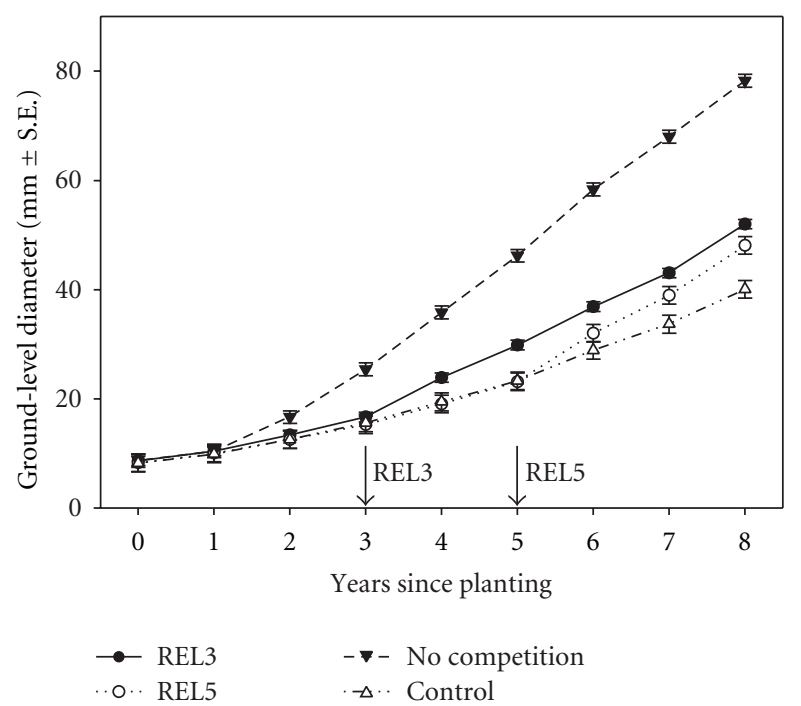

Figure 4: Profile of ground-level diameter over eight growing seasons, for large containerized and bareroot Picea glauca seedlings outplanted in south central Quebec (Canada). Treatments consisted of four intensities of vegetation management, including a control, mechanical release during the third growing season (REL3), mechanical release during the fifth growing season (REL5), and plots where competition for light was eliminated through repeated herbicide and mechanical release treatments (No competition: NC).

height/diameter ratios in control plots, compared to plots subjected to some kind of vegetation management [45]. Nevertheless, the height/diameter ratios remained well below critical levels for plantation stability [3], even in control plots. Concomitant with the general pattern observed elsewhere (e.g., $[46,47]$ ), resource competition by noncrop species had limited influence on seedling survival in the short term. However, competition pressure in control plots is expected to induce mortality in the longer term, compared to treated plots [48], which, in turn, will have a significant impact on crop-tree production [49].

Delaying mechanical release by two years did not impact crop tree survival but significantly affected seedling dimensions eight years after planting. The effect of release treatment on diameter growth was perceptible within a year following each treatment application (Figure 4). By year 7, diameter growth rates were similar in both REL3 and REL5 treatments $\left(P=0.862 ; 6.6 \mathrm{~mm} \mathrm{y}^{-1}\right.$ in 2005 , and $9.0 \mathrm{~mm} \mathrm{y}^{-1}$ in 2006). But, after eight growing seasons, REL5 seedlings had yet to catch up with REL3 seedlings in terms of absolute dimensions, even though the height and diameter differences could be considered of limited silvicultural impact. These results differ slightly from those reported by $\mathrm{Fu}$ et al. [46], who compared tenth-year effects of delayed aerial glyphosate applications from year 1 to 5: at the end of their experiment, all treatments had produced similar-sized saplings. As illustrated in Figure 7, REL3 provided the crop-trees with $\sim 85 \%$ full sunlight during at least two seasons (4 and 5) during which REL5 seedlings continued to receive $<60 \%$ PAR. Although it was not measured, \%PAR in REL5 most certainly reached $>80 \%$ in 2004 (the sixth growing season), the year 


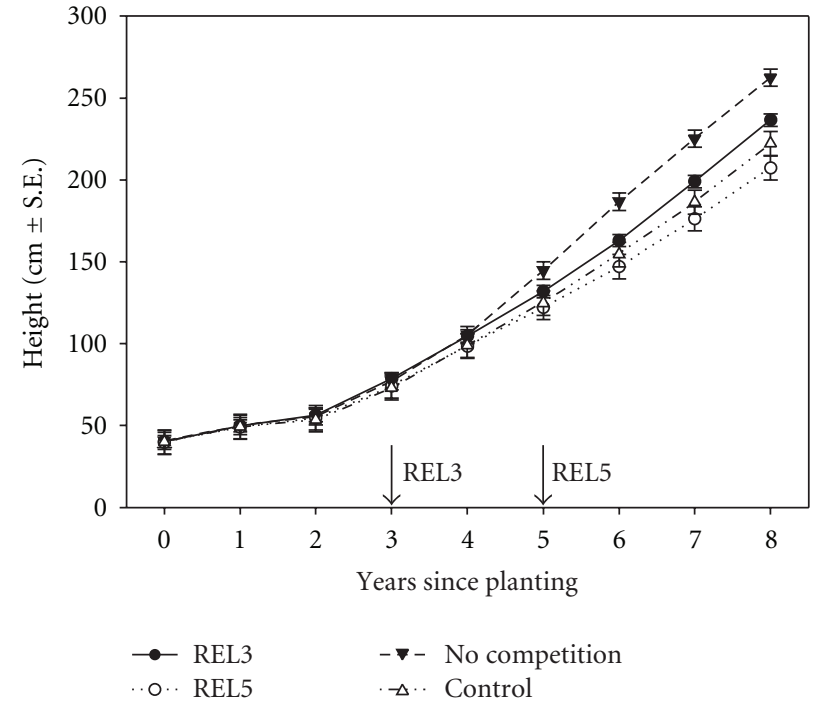

(a)

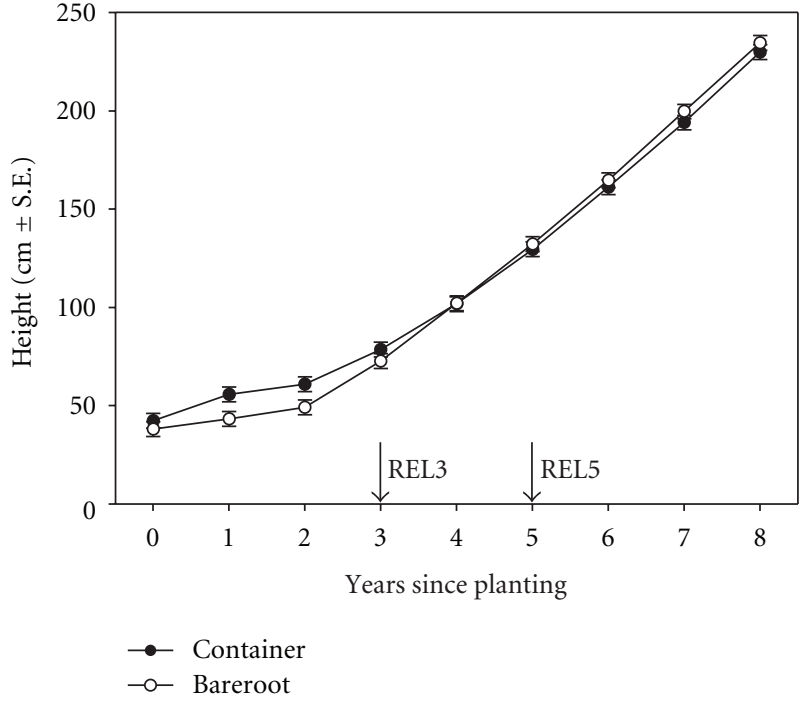

(b)

Figure 5: Profile of height over eight growing seasons of large Picea glauca seedlings outplanted in south central Quebec (Canada). (a) Presents height for each of four vegetation management treatments that were compared. Treatments consisted of four intensities of vegetation management, including a control, mechanical release during the third growing season (REL3), mechanical release during the fifth growing season (REL5), and plots where competition for light was eliminated through repeated herbicide and mechanical release treatments (No competition: NC). (b) Presents height by stock type.

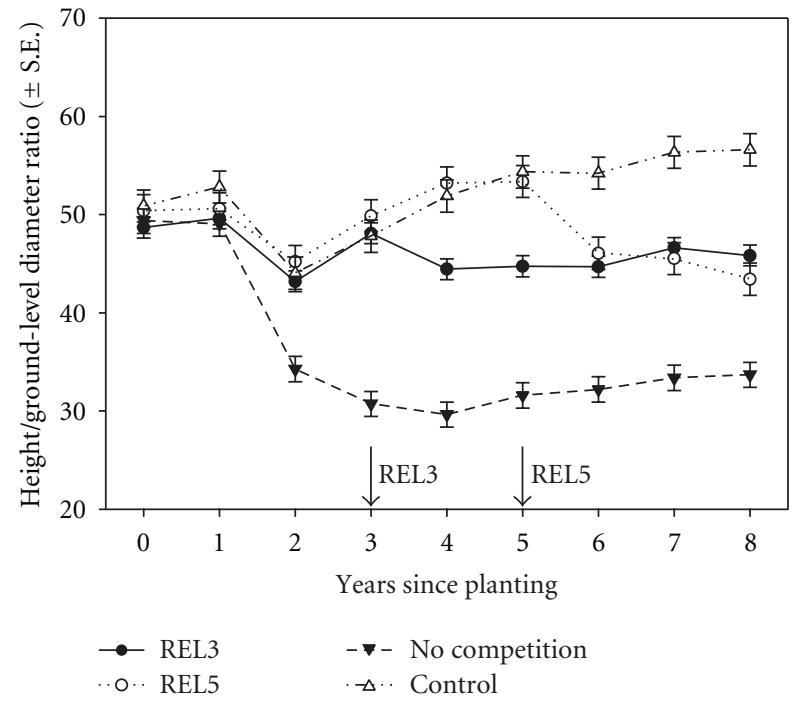

(a)

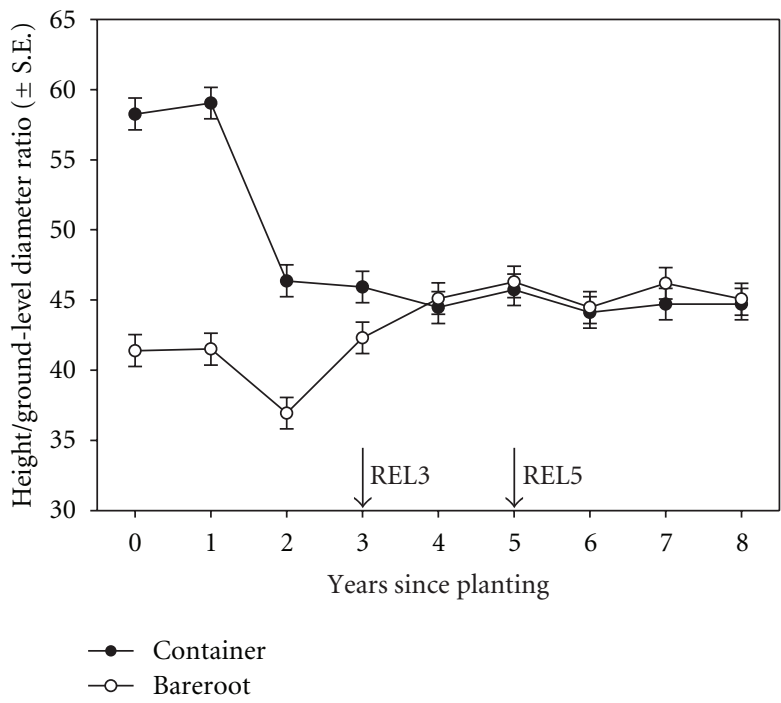

(b)

FIGURE 6: Profile of height/ground-level diameter ratio over eight growing seasons of large Picea glauca seedlings outplanted in south central Quebec (Canada). (a) Presents height/ground-level diameter ratio for each of four vegetation management treatments that were compared. Treatments consisted of four intensities of vegetation management, including a control, mechanical release during the third growing season (REL3), mechanical release during the fifth growing season (REL5), and plots where competition for light was eliminated through repeated herbicide and mechanical release treatments (No competition: NC). (b) Presents height/ground-level diameter ratio by stock type.

following the mechanical release. Despite the fact that the differences in eighth-year seedling size between the REL3 and REL5 treatments might be considered marginal, our results suggest that the guidelines that were developed with standard size seedlings to evaluate the need for mechanical release [15] are also applicable to the large stock types used in this study. It must however be noted that white spruce is considered equally or less shade tolerant than black spruce (Picea mariana (Mill.) BSP) [50], the species for which the guidelines were first developed.

Overall, the REL3 and REL5 effects on seedling dimensions concur with treatment impacts on vegetation cover and available light. On all sites, and for most species groups, percent cover had reached similar levels in both mechanical 


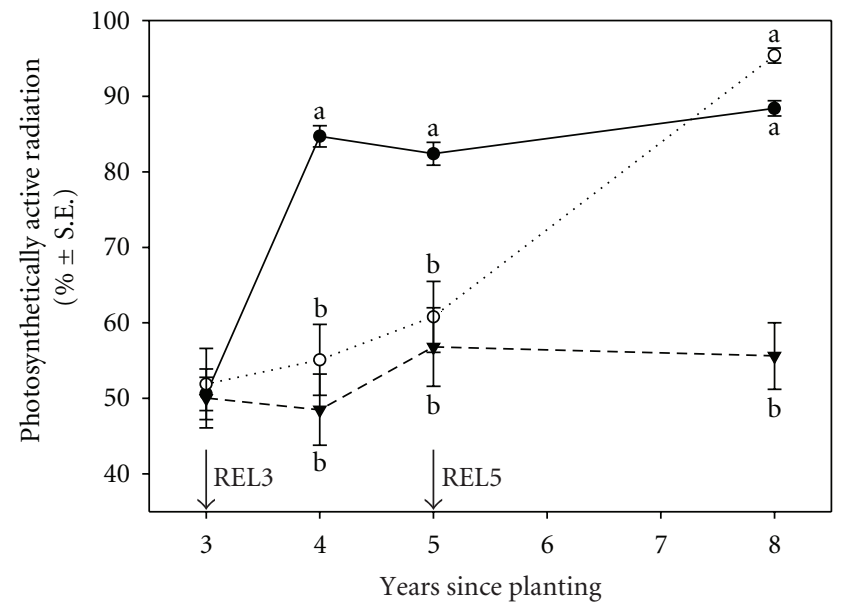

$\bullet$ REL3

. O. REL5

$-\boldsymbol{\nabla}$ - Control

FIGURE 7: Average percent of full sunlight (\%PAR) reaching the upper half of large containerized and bareroot Picea glauca seedlings outplanted in south central Quebec (Canada) over eight growing seasons. \%PAR was assessed based on the method described by Jobidon [30]. Treatments consisted of four intensities of vegetation management, including a control, mechanical release during the third growing season (REL3), and mechanical release during the fifth growing season (REL5). The fourth treatment (No competition; NC) was not included in the analyses, as by definition it consisted of the complete elimination of any competition for light, using repeated herbicide and mechanical release treatments. Values were therefore $100 \%$ under the NC treatment over the entire experimental period.

release treatments by the eighth growing season after planting (Figure 1). Although hardwoods had time to grow taller in the REL3 treatments than in the REL5 treatment, the difference was not enough to influence \%PAR, since planted white spruce seedlings were about $1 \mathrm{~m}$ taller than the hardwood competition.

Despite our efforts to create and maintain competitionfree plots with repeated herbicide and mechanical treatments in NC plots, vegetation data illustrates that none of the vegetation groups were completely eradicated from plots subjected to this treatment. Pitt et al. [42] also reported percent cover value $>0$ for plots submitted to annual removal of vegetative competition. Thus, although we clearly eliminated competition for light under the NC treatment (considering the maximum height of the competing cover, Figure 2, compared to seedling height, Figure 5), we failed to create phytometers in which the seedlings were able to express their full growth potential; competition for soil resources is likely to have influenced seedling growth in these plots. When available, such plots can serve as benchmark to measure the overall effects of competition [51].

Nevertheless, the loss of individual tree volume in REL3 and REL5 plots, compared to the NC plots, was 56\% and $66 \%$, respectively (estimated as the volume of a cone). This result illustrates how mechanical release alone does not promote optimal crop-tree growth, owing to the rapid resprouting of northern hardwoods, shrubs, and herbaceous competition [6]. Moreover, herbaceous species that are not controlled by mechanical release are significant competitors for water and nutrients $[52,53]$. In a recent review, Thiffault and Roy [14] described how this aspect of the herbicide-free approach to vegetation management poses major challenges to intensive silviculture, especially in areas where there is an expectation for a high volume of lumber and fibre for pulp and paper production. The potential advantage of such an approach, with regard to the conservation of biodiversity at the stand level [54], must be balanced against its impact on crop-tree productivity at the landscape level [55].

\section{Acknowledgments}

The authors thank S. Désalliers, J.-F. Lamarre, J.-G. Élie, G. St-Pierre, C. Villeneuve, D. Bergeron, G. Rhéaume, K. Dion, and P. Moreault for their contribution to field work and are indebted to R. Vermette for his contribution to the statistical analyses. They also express their gratitude to two anonymous reviewers for their helpful comments on an earlier draft. This study is part of project 112310031 of the Direction de la recherche forestière, Ministère des Ressources naturelles et de la Faune du Québec.

\section{References}

[1] A. Paquette and C. Messier, "The role of plantations in managing the world's forests in the Anthropocene," Frontiers in Ecology and the Environment, vol. 8, no. 1, pp. 27-34, 2010.

[2] P. Balandier, C. Collet, J. H. Miller, P. E. Reynolds, and S. M. Zedaker, "Designing forest vegetation management strategies based on the mechanisms and dynamics of crop tree competition by neighbouring vegetation," Forestry, vol. 79, no. 1, pp. 3-27, 2006.

[3] R. Jobidon, "Density-dependent effects of northern hardwood competition on selected environmental resources and young white spruce (Picea glauca) plantation growth, mineral nutrition, and stand structural development-a 5-year study," Forest Ecology and Management, vol. 130, no. 1-3, pp. 77-97, 2000.

[4] M. Newton, "Taking charge in forest vegetation management," Canadian Journal of Forest Research, vol. 36, no. 10, pp. 23572363, 2006.

[5] R. G. Wagner, "Toward integrated forest vegetation management," Journal of Forestry, vol. 92, no. 11, pp. 26-30, 1994.

[6] A. Wiensczyk, K. Swift, A. Morneault, N. Thiffault, K. Szuba, and F. W. Bell, "An overview of the efficacy of vegetation management alternatives fo conifer regeneration in boreal forests," Forestry Chronicle, vol. 87, no. 2, pp. 175-200, 2011.

[7] J. E. E. Dampier, F. W. Bell, M. St-Amour, D. G. Pitt, and N. J. Luckai, "Cutting versus herbicides: tenth-year volume and release cost-effectiveness of sub-boreal conifer plantations," Forestry Chronicle, vol. 82, no. 4, pp. 521-528, 2006.

[8] R. G. Wagner, K. M. Little, B. Richardson, and K. McNabb, "The role of vegetation management for enhancing productivity of the world's forests," Forestry, vol. 79, no. 1, pp. 57-79, 2006.

[9] R. A. Lautenschlager and T. P. Sullivan, "Effects of herbicide treatments on biotic components in regenerating northern forests," Forestry Chronicle, vol. 78, no. 5, pp. 695-731, 2002. 
[10] K. I. Swift and F. W. Bell, "What are the environmental consequences of using silviculturally effective forest vegetation management treatments?" Forestry Chronicle, vol. 87, no. 2, pp. 201-216, 2011.

[11] S. Wyatt, M. -H. Rousseau, S. Nadeau, N. Thiffault, and L. Guay, "Social concerns, risk and the acceptability of forest vegetation management alternatives: insights for managers," Forestry Chronicle, vol. 87, no. 2, pp. 274-289, 2011.

[12] Forest Stewardship Council, FSC Principles and Criteria for Forest Stewardship, 1996.

[13] N. McCarthy, N. S. Bentsen, I. Willoughby, and P. Balandier, "The state of forest vegetation management in Europe in the 21st century," European Journal of Forest Research, vol. 130, no. 1, pp. 7-16, 2011.

[14] N. Thiffault and V. Roy, "Living without herbicides in Québec (Canada): historical context, current strategy, research and challenges in forest vegetation management," European Journal of Forest Research, vol. 130, no. 1, pp. 117-133, 2011.

[15] R. Jobidon, "Light threshold for optimal black spruce (Picea mariana) seedling growth and development under brush competition," Canadian Journal of Forest Research, vol. 24, no. 8, pp. 1629-1635, 1994.

[16] R. G. Wagner and A. P. Robinson, "Critical period of interspecific competition for four northern conifers: 10-year growth response and associated vegetation dynamics," Canadian Journal of Forest Research, vol. 36, no. 10, pp. 2474-2485, 2006.

[17] R. Jobidon, V. Roy, and G. Cyr, "Net effect of competing vegetation on selected environmental conditions and performance of four spruce seedling stock sizes after eight years in Québec (Canada)," Annals of Forest Science, vol. 60, no. 7, pp. 691-699, 2003.

[18] R. Jobidon, L. Charette, and P. Y. Bernier, "Initial size and competing vegetation effects on water stress and growth of Picea mariana (Mill.) BSP seedlings planted in three different environments," Forest Ecology and Management, vol. 103, no. 2-3, pp. 293-305, 1998.

[19] A. A. Alm, "Black and white spruce planting in Minnesota: container vs. bareroot and fall vs spring planting," The Forestry Chronicle, vol. 59, no. 4, pp. 189-191, 1983.

[20] K. Johansson, U. Nilsson, and H. L. Allen, "Interactions between soil scarification and Norway spruce seedling types," New Forests, vol. 33, no. 1, pp. 13-27, 2007.

[21] T. L. Noland, G. H. Mohammed, and R. G. Wagner, "Morphological characteristics associated with tolerance to competition from herbaceous vegetation for seedlings of jack pine, black spruce, and white pine," New Forests, vol. 21, no. 3, pp. 199215, 2001.

[22] P. M. McDonald, "Container seedlings outperform barefoot stock: survival and growth after 10 years," New Forests, vol. 5, no. 2, pp. 147-156, 1991.

[23] P. A. Menes, K. D. Odlum, and J. M. Paterson, "Comparative performance of bareroot and container-grown seedlings: an annotated bibliography," in Ontario Ministry of Natural Ressources, Ontario Forest Research Institute, Sault Ste. Marie, Canada, 1996, Forest Research Information Paper 132.

[24] S. Jutras, N. Thiffault, and A. D. Munson, "Comparing large bareroot and container stock: water stress as influenced by peat and soil water availability," Tree Planters' Notes, vol. 52, no. 1, pp. 15-18, 2007.

[25] N. Thiffault, "Mechanical stability and root seedling characteristics in the large planting stocks of Picea mariana products in containers or as bare-root stocks," Forestry Chronicle, vol. 86, no. 4, pp. 469-476, 2010.
[26] N. Thiffault, R. Jobidon, and A. D. Munson, "Performance and physiology of large containerized and bare-root spruce seedlings in relation to scarification and competition in Québec (Canada)," Annals of Forest Science, vol. 60, no. 7, pp. 645-655, 2003.

[27] J. P. Saucier, P. Grondin, A. Robitaille et al., "Écologie forestière," in Manuel de Foresterie, Ordre des ingénieurs forestiers du Québec, Québec, Canada, 2nd edition, 2009.

[28] Environment Canada, "Canadian climate normals 19712000," 2010, http://climate.weatheroffice.gc.ca .

[29] R. Jobidon and L. Charette, "The effectiveness of single or repeated manual release and the cutting period of competing vegetation on the growth of black spruce seedling after 10 years," Canadian Journal of Forest Research, vol. 27, no. 12, pp. 1979-1991, 1997.

[30] R. Jobidon, "Measurement of light transmission in young conifer plantations: a new technique for assessing herbicide efficacy," Northern Journal of Applied Forestry, vol. 9, no. 3, pp. 112-115, 1992.

[31] D. C. Montgomery, Design and Analysis of Experiments, John Wiley and Sons, New York, NY, USA, 6th edition, 2005.

[32] SAS Institute, SAS/STAT 9.2 User's Guide, SAS Institute, Cary, NC, USA, 2009.

[33] R. C. Littell, G. A. Milliken, W. W. Stroup, R. D. Wolfinger, and O. Schabenberger, SAS System for Mixed Models, SAS Institute, Cary, NC, USA, 2nd edition, 2006.

[34] D. B. South and R. J. Mitchell, “Determining the 'optimum' slash pine seedling size for use with four levels of vegetation management on a flatwoods site in Georgia, U.S.A," Canadian Journal of Forest Research, vol. 29, no. 7, pp. 1039-1046, 1999.

[35] D. B. South and J. L. Rakestraw, "Large-diameter seedlings: a method of reducing chemical use in some pine plantations," Journal of Sustainable Forestry, vol. 18, no. 4, pp. 47-58, 2004.

[36] G. H. Mohammed, G. R. McLeod, P. A. Menes, and V. R. Timmer, "A comparison of bareroot and container stock," in Regenerating the Canadian Forest: Principles and Practices for Ontario, R. G. Wagner and S. J. Columbo, Eds., Fitzhenry \& Whiteside, Markham, Canada, 2001.

[37] C. Opio, N. Jacob, and D. Coopersmith, "Height to diameter ratio as a competition index for young conifer plantations in northern British Columbia, Canada," Forest Ecology and Management, vol. 137, no. 1-3, pp. 245-252, 2000.

[38] U. Nilsson and G. Orlander, "Effects of regeneration methods on drought damage to newly planted Norway spruce seedlings," Canadian Journal of Forest Research, vol. 25, no. 5, pp. 790-802, 1995.

[39] F. Trottier, Performance des Plantations Établies par le Ministère des Ressources Naturelles, Dans les Forêts Publiques du Québec, de 1986 à 1995, Ministère des Ressources Naturelles, Québec, Canada, 1998.

[40] S. C. Grossnickle and T. J. Blake, "Water relation patterns of bare-root and container jack pine and black spruce seedlings planted on boreal cut-over sites," New Forests, vol. 1, no. 2, pp. 101-116, 1987.

[41] MRNFP, Pertinence de l'Utilisation de Plants à Racines Nues Pour le Reboisement au Québec, Ministère des Ressources Naturelles, Québec, Canada, 2004.

[42] D. G. Pitt, A. E. Morneault, P. Bunce, and F. W. Bell, "Five years of vegetation succession following vegetation management treatments in a jack pine ecosystem," Northern Journal of Applied Forestry, vol. 17, no. 3, pp. 100-109, 2000.

[43] R. M. Lanner, "On the insensitivity of height growth to spacing," Forest Ecology and Management, vol. 13, no. 3-4, pp. 143-148, 1985. 
[44] S. M. Zedaker, H. E. Burkhart, and A. R. Stage, "General principles and patterns of conifer growth and yield," in Forest Vegetation Management for Conifer Production, J. D. Walstad and P. J. Kuch, Eds., John Wiley \& Sons, New York, NY, USA, 1987.

[45] C. Opio, K. Van Diest, and N. Jacob, "Intra-seasonal changes in height to diameter ratios for lodgepole pine in the central interior of British Columbia," Western Journal of Applied Forestry, vol. 18, no. 1, pp. 52-59, 2003.

[46] S. Fu, H. Y. H. Chen, F. W. Bell, M. Sharma, J. R. Delaney, and G. Peterson, "Effects of timing of glyphosate application on jack pine, black spruce, and white spruce plantations in northern Manitoba," Forestry Chronicle, vol. 84, no. 1, pp. 37-45, 2008.

[47] G. B. MacDonald and D. J. Thompson, "Responses of planted conifers and natural hardwood regeneration to harvesting, scalping, and weeding on a boreal mixedwood site," Forest Ecology and Management, vol. 182, no. 1-3, pp. 213-230, 2003.

[48] G. Cyr and N. Thiffault, "Long-term black spruce plantation growth and structure after release and juvenile cleaning: a 24year study," Forestry Chronicle, vol. 85, no. 3, pp. 417-426, 2009.

[49] F. W. Bell, J. Dacosta, M. Penner et al., "Longer-term volume trade-offs in spruce and jack pine plantations following various conifer release treatments," Forestry Chronicle, vol. 87, no. 2, pp. 235-250, 2011.

[50] H. Nienstaedt and J. C. Zasada, "Picea glauca (Moench) voss," in Silvics of North America, R. M. Burns and B. H. Honkala, Eds., vol. 1 of Agriculture Handbook 654, USDA Forest Service, Washington, DC, USA, 1990.

[51] P. J. Burton, "Some limitations inherent to static indices of plant competition," Canadian Journal of Forest Research, vol. 23, no. 10, pp. 2141-2152, 1993.

[52] F. W. Bell, M. T. Ter-Mikaelian, and R. G. Wagner, "Relative competitiveness of nine early-successional boreal forest species associated with planted jack pine and black spruce seedlings," Canadian Journal of Forest Research, vol. 30, no. 5, pp. 790-800, 2000.

[53] D. G. Pitt, A. Morneault, W. C. Parker, A. Stinson, and L. Lanteigne, "The effects of herbaceous and woody competition on planted white pine in a clearcut site," Forest Ecology and Management, vol. 257, no. 4, pp. 1281-1291, 2009.

[54] M. J. Hartley, "Rationale and methods for conserving biodiversity in plantation forests," Forest Ecology and Management, vol. 155, no. 1-3, pp. 81-95, 2002.

[55] J. Dacosta, K. Szuba, F. W. Bell et al., "Modelling landscapelevel effects of reduced herbicide use in two forests in Northern Ontario," Forestry Chronicle, vol. 87, no. 2, pp. 290-309, 2011. 

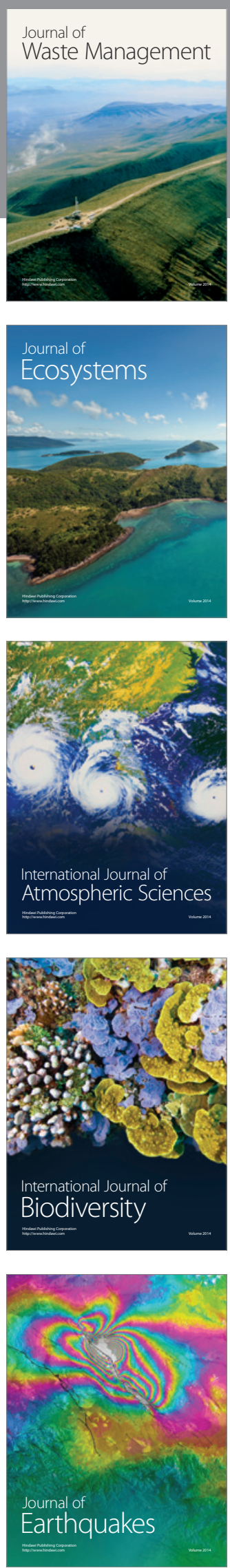
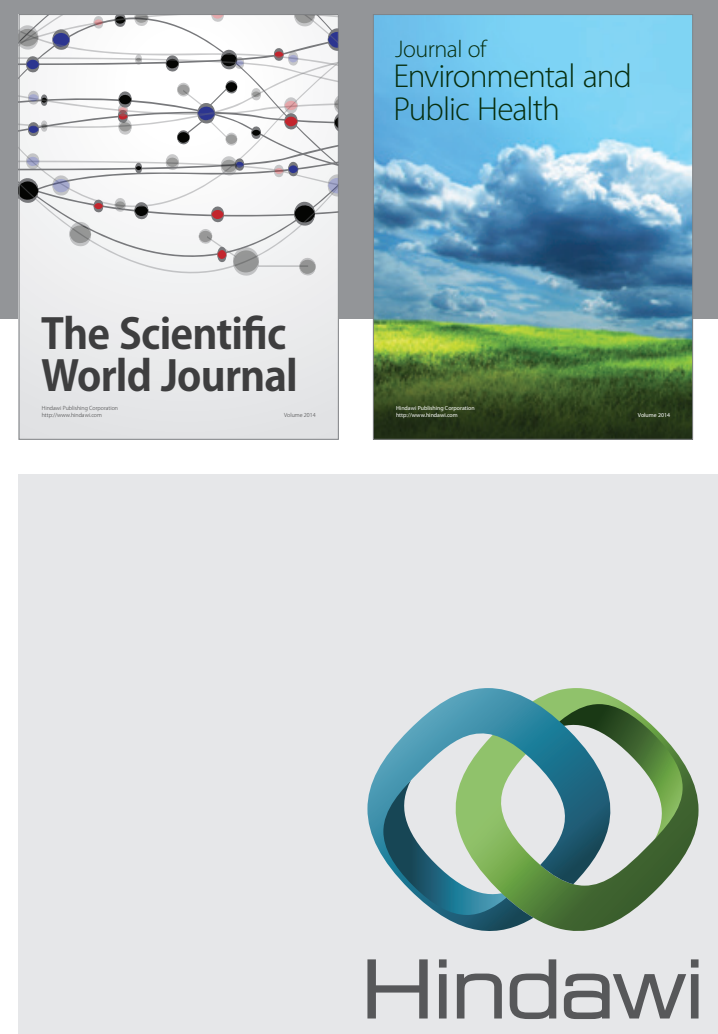

Submit your manuscripts at

http://www.hindawi.com
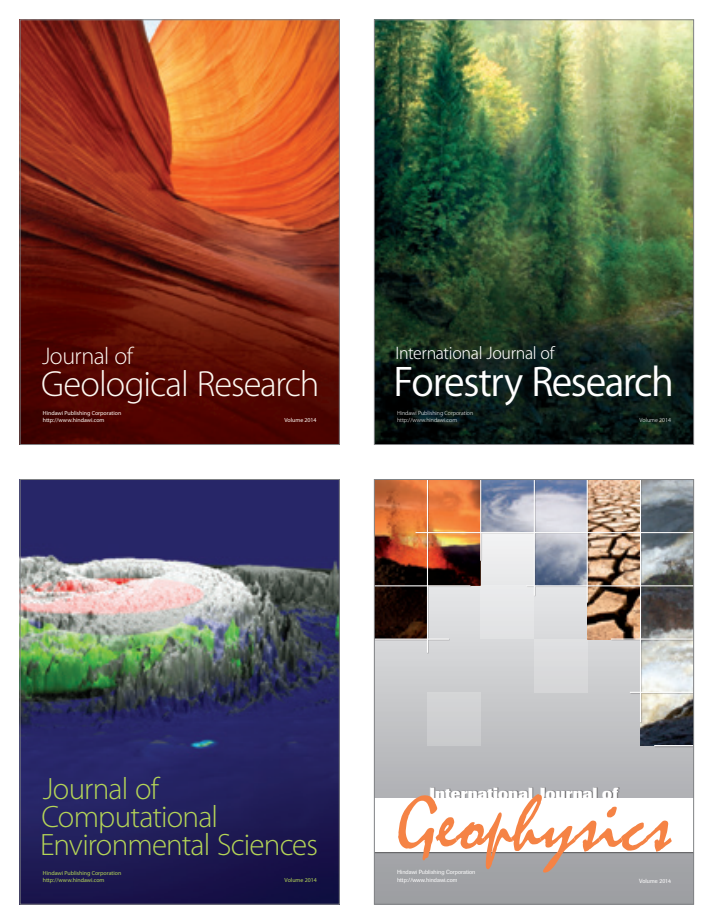
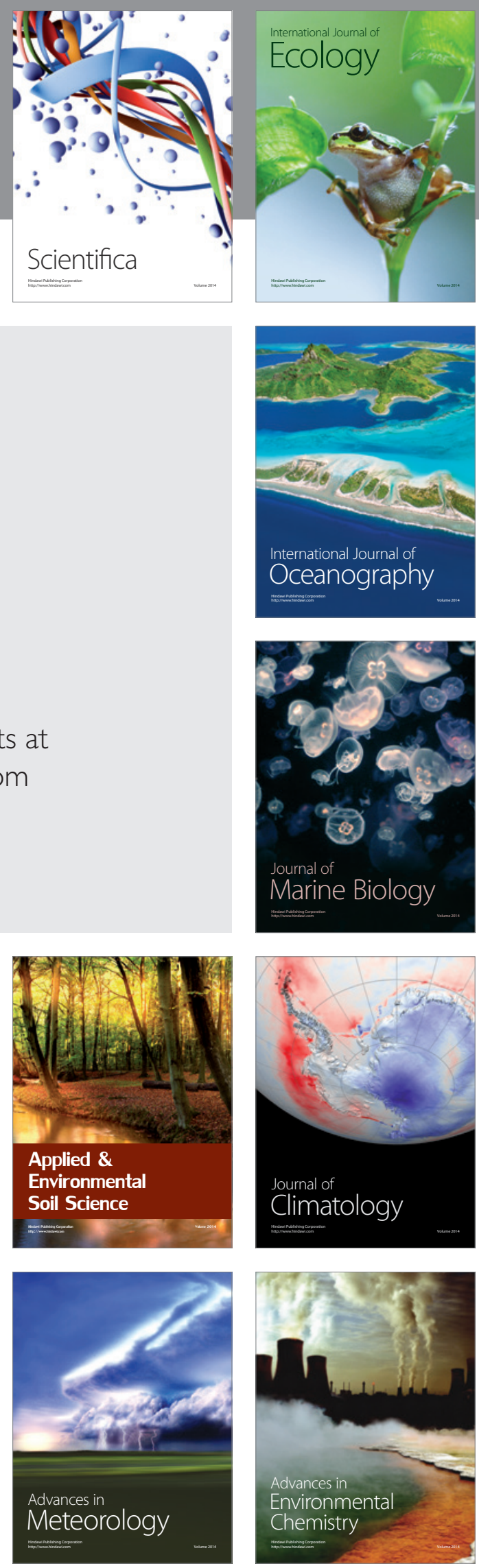